\title{
Research Square \\ An Extended Sepic DC-DC Converter for Micro-Grid Based Photovoltaic (Pv) Applications.
}

\section{HUZAIFA ISAH ( $\nabla$ huzaifa.isah@fubk.edu.ng )}

Federal University Birnin Kebbi https://orcid.org/0000-0002-3411-1249

\section{Abdu Yunusa}

Bayero University Kano.

\section{Mukhtar Ali Hajara}

Bayero University kano, Nigeria

\section{Research Article}

Keywords: DC-DC Converter, Voltage gain, Duty-cycle, Voltage Stress, PV Panels

Posted Date: February 4th, 2022

DOI: https://doi.org/10.21203/rs.3.rs-1274799/v1

License: (1) This work is licensed under a Creative Commons Attribution 4.0 International License. Read Full License 


\begin{abstract}
Background: The demands for clean energy is growing rapidly and the fossil fuel we use in our everyday live is ushered in $\mathrm{CO}_{2}$ and other greenhouse effects, resulting in natural disasters and other climate threats. To continue on this route, the world is challenged to prepare for the unknown disasters. Hence, the search for a clean, alternative energy resource, which could bring resilience back to our cities is in incredibly rapid velocity. Solar energy is a clean and alternative energy that can be use but PV panels tend to generate low energy in nature which is why a lot of panels have to be employed in order to go off-grid. A simple DC-DC converter can be used to boost the energy generated by PV panels. Provided herein is an extended DC-DC single ended primary inductor converter (SEPIC) for micro-grid based photovoltaic (PV) applications. The new topology was designed with an addition of some components to the conventional SEPIC.

Results: The extended SEPIC topology utilizes a single power switch with high voltage gain, low duty-cycle, reduced voltage stress across the power switch, low density and cheap. The new topology was designed with an addition of some components to the conventional SEPIC. A $125 \mathrm{~V}$ DC output was generated from a $12 \mathrm{~V}$ DC input through MATLAB/SIMULINK. The new SEPIC converter revealed the best value voltage gain as 10.42 , duty-cycle value of 0.8 and voltage stress of $62.5 \mathrm{~V}$ compared to the conventional SEPIC or SEPIC integrated with other converters.
\end{abstract}

Conclusions: the results of voltage gain, duty-cycle and voltage stress obtained validate the credibility of the new converter and show the potentiality of the converter for the adoption in power step-up applications.

Keywords: DC-DC Converter, Voltage gain, Duty-cycle, Voltage Stress, PV Panels.

\title{
1.0 Background
}

For a sustainable clean city, there is a need to limit the fossil fuel usage and maximize the use of alternative energy resources (renewables) as a source of electricity generation. These abundant resources are promising for the future due to their reversibility, easy operation, less maintenance, and zero pollution of the environment. There are many forms of renewables with solar power the most common we use today [1-4].

Photovoltaic (PV) panels are solar powers made up of semiconductor materials that absorb heat from sun and convert it into electricity [5-7]. The semiconductor cells on the panel are designed in series or parallel arrangement to get the best energy generation [8]. Lack of sufficient area for installation, low sunshine, shades of trees and tall buildings are some of the biggest threats affecting their performances $[9,10]$. Therefore, PV per voltage generation tends to be low in nature which is why the power converter technology is much-needed [5], [11, 12]. This technology can be used to step up the low DC voltage generated by the PV panel into the desired output value [13, 14]. There are many types of power converter but at this junction, a DC-DC type is required.

The DC-DC power converters are of many types, transformerless and those with transformers [11]. The transformer types were deemed too expensive and higher voltage gain can be attained by two things, turn-ratio and duty-cycle of the transformer [10]. The transformerless types have duty cycle only as a requisite to achieve higher voltage gain, some of their structures are well exploited in the 
literature [2], [15-17]. A conventional boost converter is transformerless and it has a good duty cycle, but the voltage gain is always lower than expectations. A transformerless SEPIC is promising only when it is integrated with another converter or incorporated with voltage doubler [4], [14]. Zeta and Cuk converters exhibits Buck-Boost behavior which is not viable for step up application [15]. The aforementioned problems have led researchers to quest for more methods.

Different topologies about transformerless DC-DC converters are well exploited in the literature [2], some topologies were built by integrating two or three converters together either by cascade, inversion or by incorporation with voltage multiplier cells to achieve higher voltage gain. Buck boost presented in [16] to raise the voltage gain with reliable duty-cycle. Double boost integrated with SEPIC were proposed in [14], [17-20]. Cuk and boost converters were integrated in [18, 19] to solve similar problems. Boost with voltage multiplier cells was also proposed in [4], [8], [20, 21], SEPIC integrated with boost in [22] to optimize the system.

To add to the present solutions, this paper proposed an extended SEPIC for PV panels and other renewable energy resource applications that require a step up conversion gain. The additional components involve one capacitor and two diodes to extend the voltage gain at the expense of the low duty cycle of the new SEPIC converter. The diagrammatic representation of the system is shown in fig. 1. To make the propose converter simple and lighter, the new topology utilizes a single switch. The steady-state and theoretical analysis is discussed in details. Simulation and laboratory validations were taken and presented herein.

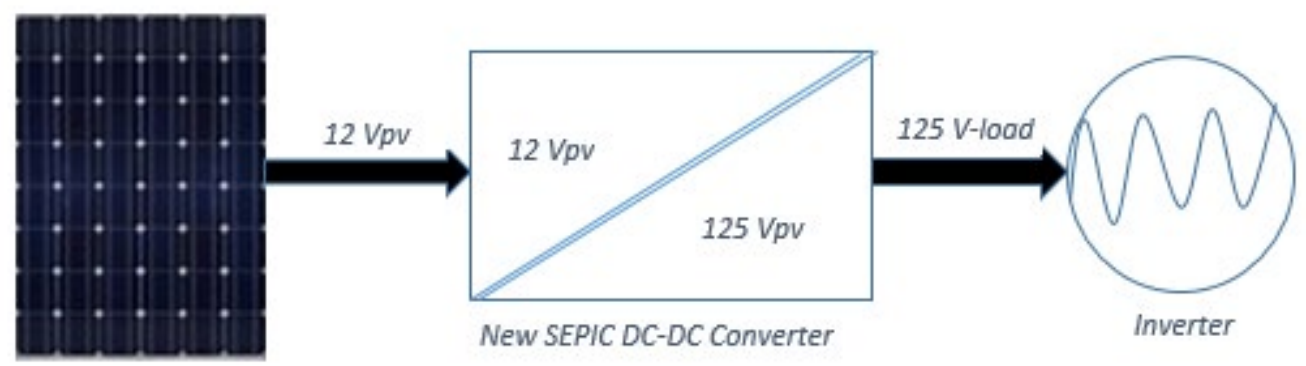

PV Panel

Figure 1: Diagrammatic representation of the system

\subsection{Methods}

The new topology is presented in figure 3 which consists of two inductance $\mathrm{L}_{1} \& \mathrm{~L}_{2}$, three diodes $\mathrm{D}_{1}, \mathrm{D}_{2}, \&$ Do, three capacitors $\mathrm{C}_{1}, \mathrm{C}_{2} \& \mathrm{C}_{\mathrm{O}}$ and one controllable power switch. As it can be seen in fig. 2, the new converter has additional two diodes and one capacitor $\left(D_{1}, D_{2} \& C_{2}\right)$ than the conventional SEPIC topology in fig. 2. In fig. 3, capacitor $C_{2}$ is placed between the two diodes such that its discharged energy would be blocked by $D_{1}$, as such, $C_{1}$ will combine the voltage coming from the power switch with the voltage coming from $C_{2}$ and dissipate it to the inductor $L_{2}$. This approach is similar but in modification to the methods adopted in a classical boost converter presented in [7] and SEPIC incorporated with voltage doubler in [4]. The method adopted in the present study is cheaper and friendly than the methods adopted in [22]. After the realization of the 
new converter, MATLAB/SIMULINK was used to run the simulation and the laboratory set up was prepared with trainer version 3371 connected with DX9 USB socket and signals were generated.

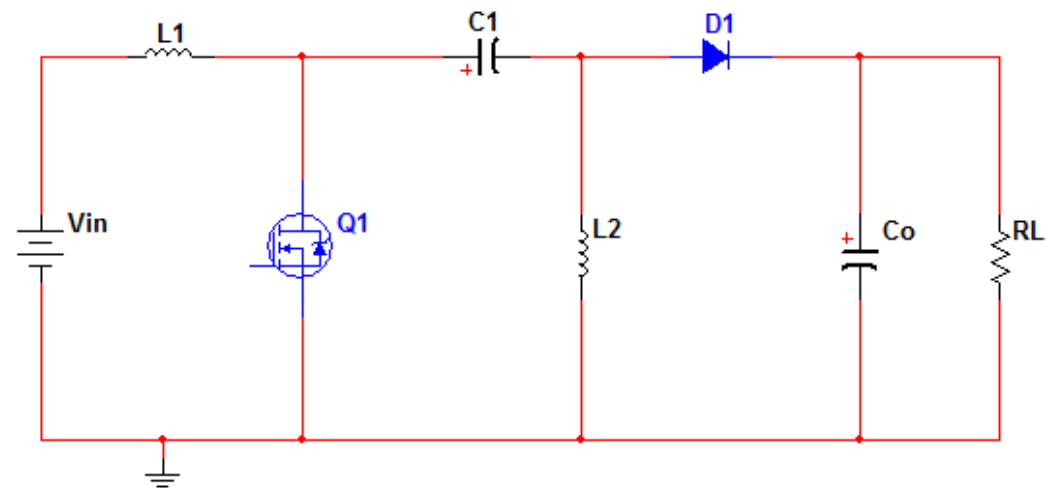

Figure 2: Conventional SEPIC Converter

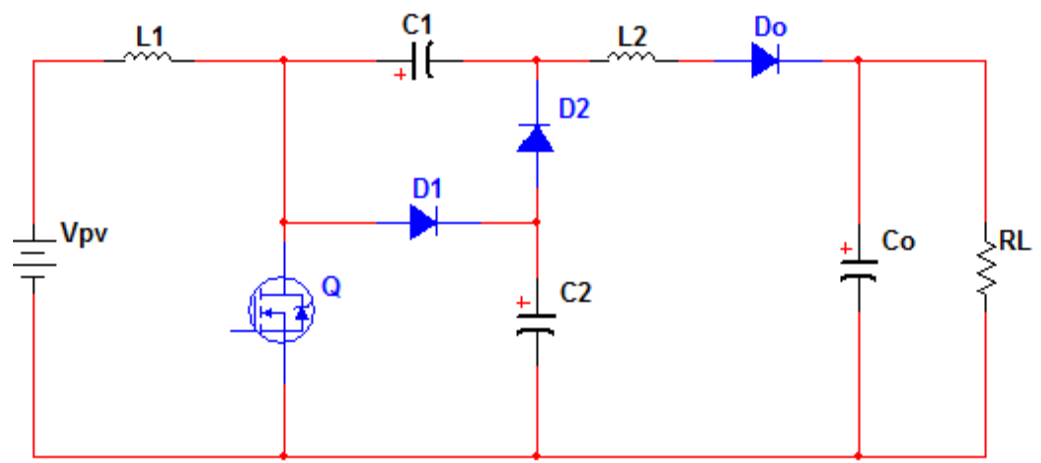

Figure 3: Proposed Extended SEPIC Converter.

The modes of operation of the extended SEPIC converter is given below:

\section{Mode 1:}

Here, the power switch $Q$ is in ON-state therefore the energy from inductor $L_{1}$ will flow through diode $D_{1}$ to $C_{2}$. The energy in $C_{2}$ would be delivered to $C_{1}$ and then to the output.

Mode 2:

In this mode, the power switch is in OFF-state therefore the leaked energy follows through inductor $\mathrm{L}_{2}$.

\subsection{Analysis of the New Converter:}

Applying Kirchhoff voltage law to the circuit in fig. 3 yields the following equation;

$V_{P V}=V_{L 1}$

Applying switching signal to the power switch (Q) yields

$V_{Q}=V_{C 2}=V_{P V} /(1-\partial)$

Equation(2) is used to evaluate voltage across the power switch \& capacitor $C_{2}$, that is, $V_{Q} \& V_{C 2}$. 
Therefore, $V_{C 1}$ will combine the voltage coming from power switch $\left(V_{Q}\right)$ with the voltage in the second capacitor $\left(V_{C 2}\right)$ and delivers it to the inductor $L_{2}$.

This is to say, $V_{C 1}=V_{Q}+V_{C 2}$

From equation (3) it can be confirmed that

$V_{\text {Load }}=V_{L 2}=V_{D O}=V_{C O}$

OR, $V_{\text {Load }}=V_{Q}+V_{C 2}$

Generally, with the effect of switching signal, the input/output relationship takes the form

$V_{P V} \partial T=\left(V_{\text {Load }}-V_{C 2}-V_{P V}\right)(1-\partial) T$

Therefore, $V_{P V} \partial=\left(V_{\text {Load }}-V_{L o a d} \partial-V_{C 2}-V_{P V}\right)(1-\partial)$

Collecting the like terms in equation (7) yields:

$\left(V_{\text {Load }}(1-\partial)-V_{C 2}(1-\partial)\right)-V_{P V}=0$

According to the equation $(2) V_{C 2}=V_{P V} /(1-\partial)$

This implies that equation (8) can be written as:

$V_{\text {Load }}=2 V_{C 2}$

$V_{\text {Load }}=V_{C 1}=V_{D O}=V_{C O}=2 V_{C 2}$

To find the duty cycle, equation (10) can be expressed in terms of equation (2):

$\partial=\left(V_{\text {Load }}-2 V_{P V}\right) / V_{\text {Load }}$

For the voltage gain, equation (7) can be rewritten as

$V_{\text {Load }} / V_{P V}=2 /(1-\partial)$

But, gain $=V_{L o a d} / V_{P V}$

Therefore, gain $=V_{L o a d} / V_{P V}=2 /(1-\partial)$

Concerning the voltage stress across the power switch, equation (2) can be considered:

$V_{Q}=V_{P V} /(1-\partial)$

\subsection{Design Equations for the New Converter.}

The following values were assumed in designing each component of the new converter.

Input voltage $V_{P V}=12 \mathrm{~V}$

Output voltage, $V_{L O A D}=125 \mathrm{~V}$

Duty cycle, $\partial=0.8$

Switching frequency, $f=20 \mathrm{kHz}$ 
Output Power $P_{O}=100 \mathrm{~W}$

Power MOSFET (IRFZ $44 \mathrm{~N}$ )

Diodes $\mathrm{D}_{1}=\mathrm{D}_{2}=\mathrm{D}_{\mathrm{o}}=$ MUR 110

\subsection{Inductance $L_{1} \& L_{2}$ :}

Values of current ripples $\left(I_{L 1} \& I_{L 2}\right)$ were used to design the inductance $L_{1} \& L_{2} .4 \mathrm{~A}$ \& 6 A were measured through laboratory set up as a current ripple values. The values of the inductance can be evaluated using equations(15) \& (16).

$$
\begin{aligned}
& L_{1}=V_{P V} x \partial / f_{S} x I_{L 1}=12 \mathrm{mH} \\
& L_{2}=V_{C_{1}} x(1-\partial) / f_{f_{S}} x I_{L 2}=10 \mathrm{mH}
\end{aligned}
$$

\subsection{Capacitors $\mathrm{C}_{1} \& \mathrm{C}_{0}$ :}

For capacitor $\mathrm{C}_{1}$, input voltage ripple $\Delta V_{\text {in }}$ in equation(17) is used. For capacitors $C_{2} \& C_{o}$ output voltage ripple $\Delta V_{L O A D}$ in equation (19) is used.

$\Delta V_{\text {in }}=V_{P V} /(1-\partial) \times 10 \%=6 \mathrm{~V}$

$\Delta V_{\text {out }}=V_{P V} /(1-\partial)=62.5 \mathrm{~V}$

Therefore, $C_{1}=I_{O} / f_{s} x \Delta V_{\text {in }}=2 \mu \mathrm{F}$

For output capacitor $\mathrm{C}_{\mathrm{o}}$,

$C_{2}=C_{o}=I_{O} / 4 \pi f_{\text {grid }} V_{L O A D} \Delta V_{L O A D}=16 \mu F$

Equation (18) is used to evaluate output current $I_{O}$

$I_{O}=C_{1} x f_{s} x \Delta V_{i n}$

Switching frequency can be evaluated using equation (21):

$f=1 / T_{T}=20 k H_{Z}$ 


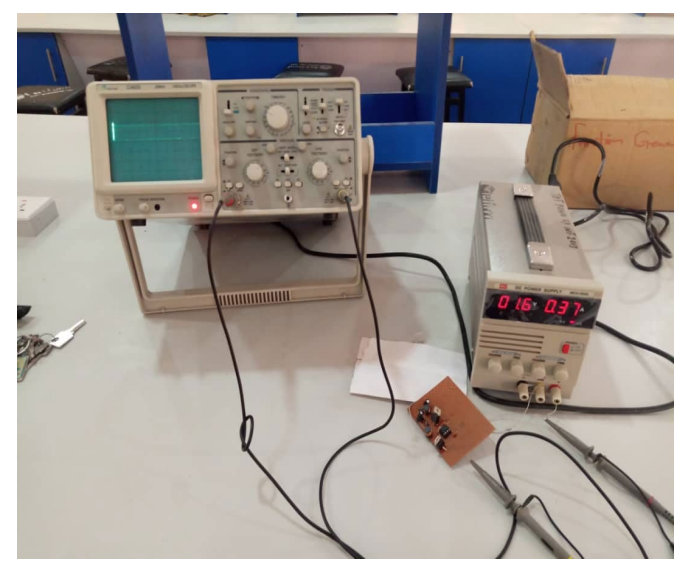

Fig. 4: Laboratory set up of the new converter.

\subsection{Result and Discussions}

\subsection{Result}

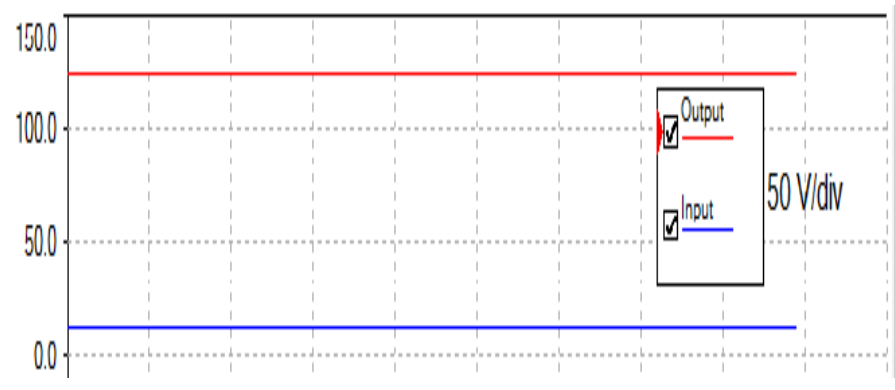

Figure 5: Input/output signals of the new converter.

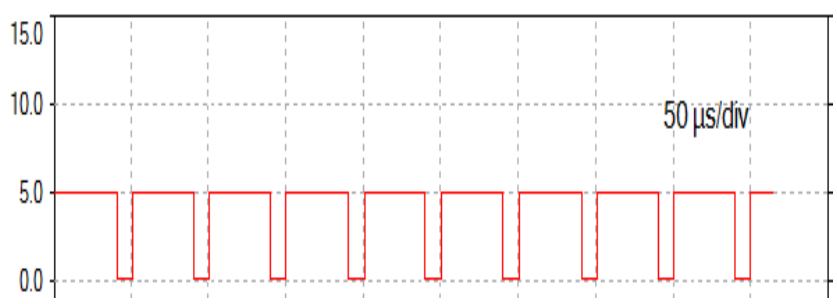

Figure 6: Switching signal $\left(V_{G S}\right)$.

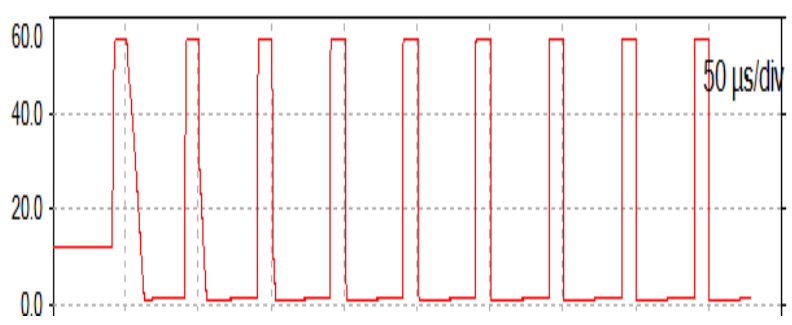

Figure 7: Voltage across diodes $\left(V_{D 1}=V_{D 2}\right)$. 


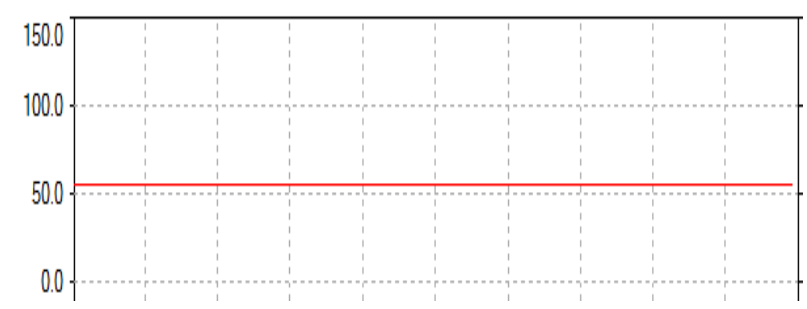

Figure 8: Voltage across $C_{2}\left(V_{C 2}\right)$.

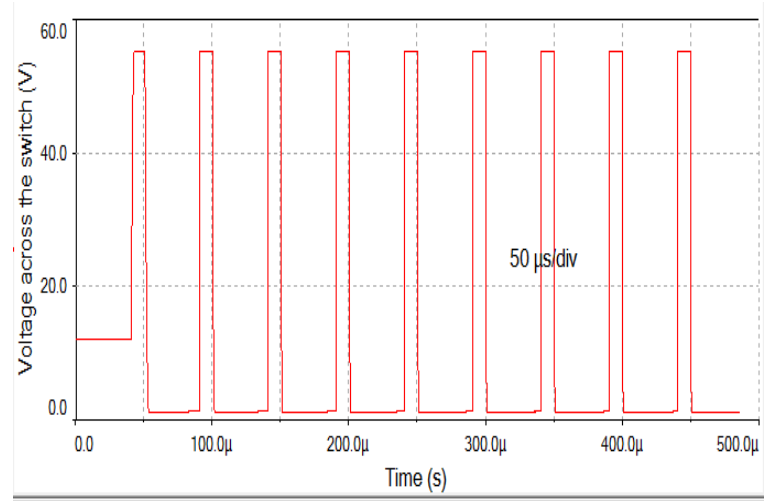

Figure 9: Voltage across power switch $\left(V_{Q}\right)$.

\subsection{Discussion}

Simulations:

MATLAB/SIMULINK was used to carry out the simulation. An output voltage of $125.232 \mathrm{~V}$ DC was realized with input and duty-cycle values of $12 \mathrm{~V} \mathrm{DC}$ and 0.8 respectively. This means a voltage gain value of 10.45 was confirmed which is in line with the equation (13). For a stress-free converter, half of the output voltage is expected to pass through the power switch. A value of about $62.5 \mathrm{~V}$ voltage across the active power switch which can also be evaluated using equation (14).

Experiment:

The prototype of the circuit was built in the laboratory as shown in fig. 3. A trainer (version 3371) connected with USB Dx9 was used to generate the signals shown in figures $4 \& 5$. Figure 4 depicts an input/output signals and it can be seen that $125 \mathrm{~V} \mathrm{DC}$ was realized from an input of $12 \mathrm{~V} \mathrm{DC}$, this means a voltage gain of 10.42 is obtained with 0.8 as a duty-cycle value. The $50 \mu$ s per division (100 $\mu$ s per 2 divisions) depicted in fig. 5 represents the period per oscillation which was used to evaluate the switching frequency in equation (21). The values obtained from the new SEPIC were compared with conventional SEPIC as shown in the fig. 6. 


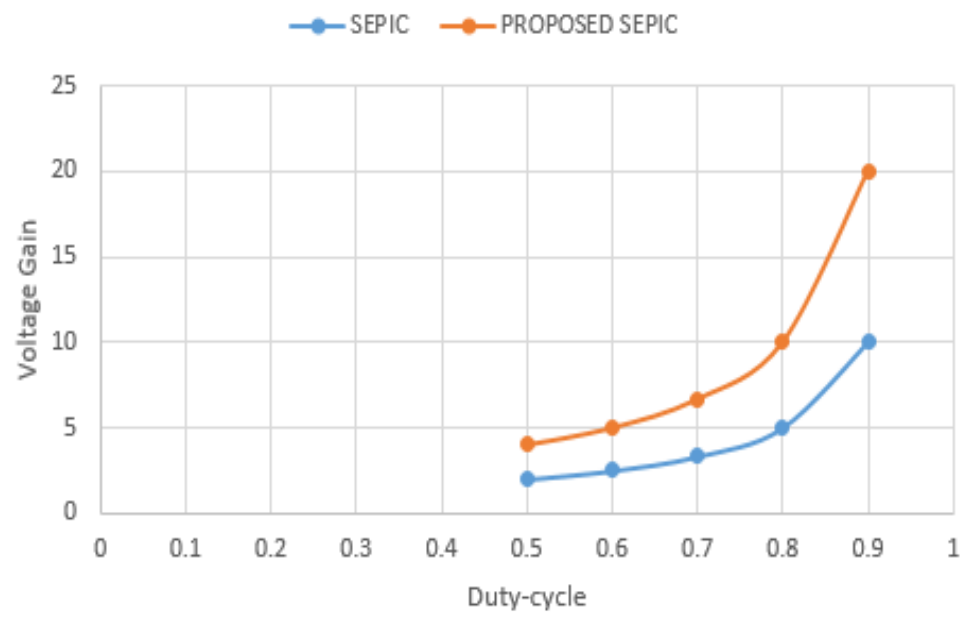

Figure 10: Comparison of Voltage gain/duty-cycle with SEPIC Converter.

\subsection{Conclusions}

An extended SEPIC DC-DC converter for micro-grid based PV panel applications is presented in this work. The new topology has shown that addition of one capacitor and two diodes to the conventional SEPIC topology can extend its voltage gain at the expense of low duty-cycle as depicted in fig. 10. The voltage stress across the power switch has been reduced to minimum.

\section{List of Abbreviations}

SEPIC: Single-ended Primary Inductor Converter; DC-DC: Direct current Direct current; PV: Photovoltaic.

\section{REFERENCES}

[1] Isah H, Sagagi YM, Tampul HM (2020) A Conventional Double Boost Converter with Voltage Multiplier Cell for Photovoltaic ( PV ) Applications. Savanna J. Basic Appl. Sci 2(1):103-108.

[2] Asim A, Amir A, Seng H, El A, Abd N (2018) Comparative Analysis of High Voltage Gain DC-DC Converter Topologies for Photovoltaic Systems. Renew. Energy 18(2):163-167. https://doi.org/10.1016/j.renene.

[3] Tewari N, Sreedevi VT, (2018) A novel single switch dc-dc converter with high voltage gain capability for solar PV based power generation systems. Sol. Energy 171(1):466-477. https://doi.org/10.1016/j.solener.

[4] Saravanan S, Ramesh-Babu N, (2017) Analysis and implementation of high step-up DCDC converter for PV based grid application. Appl. Energy 190:64-72. https://doi.org/10.1016/j.apenergy.

[5] Ahmad R, Murtaza AF, Ahmed H (2019) Power tracking techniques for efficient operation of photovoltaic array in solar applications - A review. Renew. Sustain. Energy Rev 101(2):82-102. https://doi.org/10.1016/j.rser. 
[6] Moral DL, Barrado A, Sanz M, Lázaro A, Fernández C, Zumel P (2019) Analysis and implementation of the Autotransformer Forward-Flyback converter applied to photovoltaic systems. Sol. Energy 194(2):995-1012. https://doi.org/10.1016/j.solener.

[7] Mitra L, Rout UK (2017) Performance analysis of a new high gain dc - dc converter interfaced with solar photovoltaic module. Reinf. Plast 19(1):63-74. https://doi.org/10.1016/j.ref.

[8] Krishna N, Prashanth M, Kumari NK, Krishna DSG, Kumar MP (2017) Transformer Less High Voltage Gain Step-Up DC-DC Converter Using Cascode Technique. in Energy Procedia 117:45-53. https://doi.org/10.1016/j.egypro.

[9] Gowtham S, Balaji M, Harish S, Pinto MSA, Jagadeesh G (2017) Fault Tolerant Single Switch PWM DC-DC Converters for the Battery charging Applications. in Energy Procedia 117:753-760. https://doi.org/10.1016/j.egypro.

[10] Mirzaei A, Rezvanyvardom M (2020) High voltage gain soft switching full bridge interleaved Flyback DC-DC converter for PV applications. Sol. Energy 196(2):217-227. https://doi.org/10.1016/j.solener.

[11] Isah H, Sagagi YM, Aliyu Y (2021) An Integrated Boost-Sepic Higher Static Gain DC-DC Converter for Photovoltaic ( PV ) Based Micro-Grid Application," Niger. J. Basic Appl. Sci 29(1):55-62. https://dx.doi.org/10.4314/njbas.v29i1.7.

[12] Manuel J, Enrique G, Javier A (2017) Theoretical Assessment of DC / DC Power Converters ' Basic Topologies . A Common Static Model," Appl. Sci 8(1):1-28. https://doi.org/10.3390/app80100192018.

[13] Dileep G, Singh SN (2017) Selection of non-isolated DC-DC converters for solar photovoltaic system. Renew. Sustain. Energy Rev 76(1):1230-1247. https://doi.org/10.1016/j.rser.

[14] Sabzali AJ, Ismail EH, Behbehani HM (2014) High voltage step-up integrated double Boost-Sepic DC-DC converter for fuel-cell and photovoltaic applications. Renew. Energy 16:1-10. https://doi.org/10.1016/j.renene.

[15] Bayat F, Karimi M, Taheri A (2019) Robust output regulation of Zeta converter with load / input variations: LMI approach. Control Eng. Pract 84(1):102-111. https://doi.org/10.1016/j.conengprac.

[16] Kaouane M, Boukhelifa A, Cheriti A (2016) Regulated output voltage double switch BuckBoost converter for photovoltaic energy application. Int. J. Hydrogen Energy 16:1-11. https://doi.org/10.1016/j.ijhydene.

[17] G. Kanimozhi et al., (2017) Small Signal Modeling of a DC-DC Type Double Boost Converter Integrated With SEPIC Converter Using State Space Averaging Approach. in Energy Procedia 117:835-846. https://doi.org/10.1016/j.egypro.

[18] Kumar M, Ashirvad M, Babu YN (2017) An integrated Boost-Sepic- Ćuk DC-DC converter with high voltage ratio and reduced input current ripple. Assessing the feasibility. in Energy Procedia 117:984-990. https://doi.org/10.1016/j.egypro. 
[19] Fernão V, Foito D, Fernando J (2017) A single switch hybrid DC / DC converter with extended static gain for photovoltaic applications. Electr. Power Syst. Res 146:228-235. https://doi.org/10.1016/j.epsr.

[20] Agrawal N, Gajpal T, Diwan R (2017) High Gain DC-DC Converter with Voltage Multiplier using Pulse Generation. Int. J. Sci. Eng. Technol. Res 6(4):577-581.

[21] Nakpin A, Khwan-On S (2016) A Novel High Step-up DC-DC Converter for Photovoltaic Applications. Procedia Comput. Sci 86(1):409-412. https://doi.org/10.1016/j.procs.

[22] Aprilianto RA, Semarang UN, Subiyanto S, Semarang UN (2018) Modified SEPIC Converter Performance for Grid-Connected PV Systems under Various Conditions. Telokomia 16(6):2943-2953. https://doi.org/10.12928/telkomnika.v16i6.10148. 